\title{
Antiadipogenic Effect of Vitis amurensis Root Methanol Extract and Its Solvent Fractions in 3T3-L1 Preadipocytes
}

\author{
Jung Ae Park', Kyong-Suk Jin', You Na Oh', Sook Kyung Hyun ${ }^{1,2}$, Yung Hyun Choi ${ }^{1,3}$, Hyun Ju Kwon ${ }^{1,4}$ \\ and Byung Woo Kim ${ }^{1,4}$ * \\ ${ }^{1}$ Blue-Bio Industry Regional Innovation Center, Dong-Eui University, Busan 614714, Korea
${ }^{2}$ Department of Food Science and Nutrition, College of Natural Science, Dong-Eui University, Busan 614714, Korea
${ }^{3}$ Department of Biochemistry, College of Oriental Medicine, Dong-Eui Univertisy, Busan 614-052, Korea
${ }^{4}$ Department of Life Science and Biotechnology, College of Natural Science, Dong-Eui University, Busan 614714, Korea
}

Received December 3, 2012 / Revised December 13, 2012 /Accepted December 14, 2012

\begin{abstract}
Vitis amurensis Rupreche, a sort of grape, grows naturally in Asian countries. It is known for important biological effects such as antioxidation, anti-inflammation, neuroprotection, and angiogenesis inhibition. Although its root is used as a traditional folk medicine in Korea, the root's biological activities are poorly studied. In the present study, the effects of $V$. amurensis root methanol extract (VARM) and its solvent fractions on adipocyte differentiation and adipogenesis in 3T3-L1 preadipocytes were investigated. The VARM significantly suppressed adipocyte differentiation, lipid accumulation, and the triglyceride (TG) content of 3T3-L1 preadipocytes in a dose-dependent manner, without cytotoxicity. To identify active molecules, the VARM was fractionated with a series of organic solvents including dichloromethane $\left(\mathrm{CH}_{2} \mathrm{Cl}_{2}\right)$, ethyl acetate $(\mathrm{EtOAc})$, and $n$-butanol $(n-\mathrm{BuOH})$. All the fractions also showed inhibition of lipid accumulation in the 3T3-L1 preadipocytes. The $\mathrm{CH}_{2} \mathrm{Cl}_{2}$ fraction showed the most powerful anti-obesity effect through the modulation of cytidine-cytidine-adenosine-adenosinethymidine (CCAAT)/enhancer binding protein a $(\mathrm{C} / \mathrm{EBPa}), \mathrm{C} / \mathrm{EBP} \beta$, peroxisome proliferator-activated receptor 8 (PPARy) gene and protein expression. Oleanolic acid was one of the main active compounds involved in the anti-obesity activity of the $V$. amurensis root. These results provide important new insight into the potential potent anti-adipogenic effect of the $V$. amurensis root and illustrate that one of the main compounds involved in this effect is oleanolic acid.
\end{abstract}

Key words : Vitis amurensis Rupreche root, 3T3-L1 preadipocyte, anti-adipogenic effect, oleanolic acid

\section{서 론}

체내에 지방 조직이 과다하게 축적된 상태를 의미하는 비만 (obesity)은 열량의 섭취와 소비의 불균형으로 발생하는 대사 성 질환이다. 비만은 그 자체로도 문제가 되나 특히 당뇨병, 고혈압, 고지혈증, 관절염, 심장병, 뇌졸증, 동맥경화, 지방간 등 각종 대사성 질환과 심혈관계 질환 발생의 직접적인 요인 으로 밝혀지고 있어 그 심각성이 크다[7, 21]. 세계보건기구 (WHO)는 비만으로 매년 260만 명이 사망하는 가운데 2010년 전 세계 비만 인구가 10 억에 달하며 2015년에는 15억 명으로 증가하여 심각한 건강문제를 양산할 것이라고 경고한바 있다. 이러한 현상은 우리 나라 또한 예외가 아니어서 서구화된 식

\footnotetext{
*Corresponding author

Tel : +82-51-890-2900, Fax : +82-82-51-890-2914

E-mail : bwkim@deu.ac.kr

This is an Open-Access article distributed under the terms of the Creative Commons Attribution Non-Commercial License (http://creativecommons.org/licenses/by-nc/3.0) which permits unrestricted non-commercial use, distribution, and reproduction in any medium, provided the original work is properly cited.
}

습관의 증가에 따라 국내 비만 인구도 급증하고 있어 2008년 체질량지수(Body Mass Index, BMI)가 $25\left(\mathrm{~kg} / \mathrm{m}^{2}\right)$ 이상인 비 만 인구가 $30.7 \%$ 를 차지하여 한국인 3 명 중 1 명이 비만인 시대 에 도래하였다. 비만은 지방전구세포의 분화 및 adipogenesis 과정에 의하여 지방세포의 세포 내 중성지방(triglyceride, TG) 의 축적으로 발생하며 이러한 기작을 조절하는 것이 비만 억 제의 효과적인 치료 방법으로 알려져 있다[2]. Adipogenesis, 즉 지방세포형성은 지방세포가 만들어지는 분화과정으로서 세포의 형태, 유전자 및 단백질의 발현, 호르몬 민감성의 변화 등을 동반하는데[18, 27], 이러한 adipogenesis 연구를 위한 in vitro cell model system으로는 일반적으로 mouse embryo로 부터 유래된 지방전구세포인 3T3-L1을 주로 사용하며 insulin, dexamethasone (DEX), 3-isobutyl-1-methylxanthine (IBMX) 등의 분화유도인자를 필요로 한다[6, 13]. Adipogenesis의 분자 적인 기전으로는 peroxisome proliferator-activated receptor $\gamma$ $(\mathrm{PPAR} \gamma)$ 및 cytidine-cytidine-adenosine-adenosine-thymidine (CCAAT)/enhancer binding proteins $(\mathrm{C} / \mathrm{EBPa}, \mathrm{C} / \mathrm{EBP} \beta$, $\mathrm{C} / \mathrm{EBP}$ ) 등과 같은 adipogenic transcription factor 등이 중요 한 조절자로서 관여하는 것으로 알려져 있다[23]. 이 중 
$\mathrm{C} / \mathrm{EBP} \beta$ 와 $\mathrm{C} / \mathrm{EBP} \delta$ 는 분화초기에 insulin, $\mathrm{DEX}, \mathrm{IBMX}$ 등과 같은 hormonal cocktail에 의해 일시적이고 빠르게 발현되는 반면 C/EBPa와 PPAR $\gamma$ 는 분화 후기에 발현되어 지방세포에 특이적인 유전자의 발현을 활성화 시킴으로써 분화를 더욱 촉진시켜 분화과정을 완성시킨다[24]. 또한 $\mathrm{C} / \mathrm{EBPa}$ 는 PPAR $\gamma$ 의 활성화 및 지속적인 유지뿐만 아니라 성숙한 지방세포 생성을 위한 insulin 감수성에 중요한 역할을 담당한다[36]. 분 화된 세포는 백색지방세포에서 나타나는 TG의 축적과 같은 형태적 특징과 함께 지방세포 특이적 유전자의 발현을 유발한 다. 지방세포를 가지는 동물모델에서 $\mathrm{C} / \mathrm{EBPa}$ 를 제거하였을 때 지방축적이 나타나지 않는 것이 관찰되어 효과적인 비만억 제를 위해서는 지방세포 분화과정에 관여하는 전사인자들의 활성을 억제하는 것이 매우 중요한 것으로 밝혀졌다[5,28,34].

한편 전 세계적으로 비만 치료제의 개발을 위한 다양한 연 구가 수행되고 있는 가운데 현재 시판되고 있는 비만 치료제 들의 부작용들이 보고되면서 사용 기준이 강화되는 등의 논란 이 일고 있어 우수한 효능과 함께 안전성이 높은 물질의 개발 이 요구되고 있다. 이에 특히 천연 소재로부터 부작용이 없는 항비만 효능 보유 소재를 발굴하기 위한 많은 노력이 집중되 고 있다[14, 25, 31].

왕머루(Vitis amurensis Ruprecht)는 갈매나무목 포도과의 덩굴 식물로 달고 신맛과 독특한 향을 갖는 자색의 열매가 열리는 식물이다. 열매는 식용으로 이용하거나 술을 담근다. 알려진 효능으로는 열매, 씨, 잎, 줄기 등의 항산화능 $[1,8,12$, $16,35]$, 뇌신경보호작용 $[8,12,16]$, 신생혈관억제 및 세포자연 사 유발을 통한 암세포 성장 억제 $[15,19,20]$, 미생물 성장 억제 [37], 알레르기성 염증 억제 [17, 29] 등이 있으며 활성물질로는 polyphenol [33], procyanidin [32], amurensin A, B, G 등의 oligostilbenes $[8,9,15]$, resveratrol과 그 tetramer인 heyneanol A 등의 stilbenes $[4,11,19,20]$ 등이 알려져 있다. 머루근, 즉 왕머루의 뿌리는 한방에서 약재로 사용되고 있으며 폐암 및 백혈병에 대한 항암 효과 $[19,20]$ 와 항염증[10] 활성이 보고 된 바 있으나 이외의 생리활성에 대한 연구는 극히 드물어 다양한 생리활성 보유 유무에 대한 과학적 검증이 필요하다. 이에 본 연구에서는 한방에서 약재로 사용되고 있는 머루근 추출물의 항비만 효과를 알아보고 활성 성분을 분리함으로써 기능성 소재로서의 활용 가능성을 확인해 보고자 하였다.

\section{재료 및 방법}

\section{머루근 추출물 및 분획물의 제조}

실험에 사용한 머루근은 부산광역시 소재 (주대한생약제품 에서 구입하여 사용하였으며 한국 영천이 원산지이다. $5 \mathrm{~kg}$ 의 머루근을 측량하여 분말로 파쇄한 후 시료 부피의 5 배의 methanol $(\mathrm{MeOH})$ 을 첨가하여 $65^{\circ} \mathrm{C}$ 에서 3회 반복 추출하였 다. 추출한 시료는 감압농축(N-1000S-W, EYELA, Japan) 및
동결 건조(FDU2100, EYELA, Japan)하였다. 극성 별 용매 분 획은 $\mathrm{MeOH}$ 추출물(VARM)을 감압 농축한 농축액을 물 층과 dichloromethane $\left(\mathrm{CH}_{2} \mathrm{Cl}_{2}\right)$ 층으로 분획하고, 물 층은 다시 ethyl acetate (EtOAc) 층과 물 층으로 분리하였다. 남은 물 층은 또 다시 $n$-butanol $(n-\mathrm{BuOH})$ 층과 물 $\left(\mathrm{H}_{2} \mathrm{O}\right)$ 층으로 분획 하여 각각의 분획물을 감압 농축 후 동결 건조하여 중량법으 로 각각의 수율을 계산하였다.

\section{세포 배양 및 시료 처리}

항비만 활성 분석에 사용되는 대표적인 cell model system 인 3T3-L1 preadipocyte를 American Type Culture Collection (ATCC, USA)로부터 구입하여 10\% fetal bovine serum (FBS) 및 penicillin/streptomycin이 포함된 DMEM 배지에서 배양 하였다. $0.5 \mu \mathrm{M}$ 3-isobutyl-1-methylxanthine (IBMX), $1 \mu \mathrm{M}$ dexamethasone (DEX), $10 \mu \mathrm{g} / \mathrm{ml}$ 의 insulin (이하 MDI)를 처 리하여 adipogenesis를 유도하고 머루근 추출물 및 분획물에 의한 항비만 활성을 분석하였다[25].

\section{세포 독성 유무 분석}

항비만 활성 분석 수행 전 시료가 세포생존율에 미치는 영 향을 확인함과 동시에 세포 독성을 유발하지 않는 시료의 처 리 농도를 결정하기 위해 WST assay를 수행하였다. $1 \times 10^{5}$ cell 을 24-well tissue culture plate에 분주하여 24 시간 동안 부착 시킨 후 시료를 농도 별로 처리하여 72 시간 동안 배양하였다. 시료 처리 후 WST 시약이 든 배지로 교체하여 한 시간 동안 반응시킨 후 multi-plate reader (Paradigm, Beckman, CA, USA)를 이용하여 $450 \mathrm{~nm}$ 에서 흡광도를 측정하였다. 측정값 은 3회 반복 실험의 평균값으로 나타내었으며 독성을 유발하 지 않는 농도 범위에서 이후 실험을 수행하였다.

\section{Oil Red $O$ staining을 통한 지방세포 분화 및 TG 생성 저해능 분석}

3T3-L1 preadipocyte의 adipocyte로의 분화는 상기의 MDI 를 처리하여 유도하였다. 12-well tissue culture plate에 well 당 $2 \times 10^{5}$ 개의 세포를 분주하고 2 일 후 $10 \% \mathrm{FBS}$ 가 든 배지로 교체하였다. 2 일 경과 후 $\mathrm{MDI}$ 가 든 배지로 교체하면서 시료를 농도 별로 처리하고 2 일 간격으로 총 4 회 insulin과 시료를 처리하였다. 마지막 시료를 처리하고 2 일 경과 후 위상차 현미 경을 이용하여 지방세포 분화 정도 및 시료에 의한 분화 억제 정도를 200 배 배율로 관찰하여 촬영한 후, 지방세포 분화 억제 능 및 TG 생성 저해능을 Oil Red O staining을 통해 분석하였 다. 지방세포 분화 및 시료 처리가 완료된 세포를 $1 \times$ phosphate buffered saline (PBS)로 씻어준 다음 10\% formalin으로 고정하고 Oil Red O staining solution을 처리한 후 30 분간 염색하였다. 염색 완료 후 $100 \%$ isopropanol을 사용하여 염색 된 지방을 추출하고 multi-plate reader를 이용하여 $500 \mathrm{~nm}$ 에 
서 흡광도를 측정하였다.

Reverse transcription-polymerase chain reaction (RT-PCR)을 통한 지방세포 분화 관련 유전자 발현 조절능 분석

6-Well tissue culture plate에 $3 \times 10^{5}$ 개의 세포를 분주하고 지방 생성 억제능 분석과 동일한 방법으로 시료를 처리한 후 유전자 발현 분석을 위한 RNA를 분리하여 RT-PCR로 분석하 였다. 먼저 시료 처리가 완료된 배양 세포의 total RNA를 TRIzol (Invitrogen, CA, USA)을 사용하여 추출한 후 NanoVue plus spectrophotometer (GE healthcare, WI, USA)를 이용하 여 정량하고 SuperScript ${ }^{\mathrm{TM}}$ First-Strand Synthesis System (Invitrogen)을 이용하여 cDNA를 합성한 후 $\mathrm{PCR}$ 을 수행하였 다. 유전자 발현 분석의 internal control로는 housekeeping gene인 glyceraldehydes-3-phosphate dehydrogenase (GAPDH) 를 사용하였으며 실험에 사용한 대상 유전자의 primer sequence는 Table 1 에 제시한 바와 같다.

Western blot hybridization을 통한 지방세포 분화 관련 단백질 발현 조절능 분석

상기의 RT-PCR 분석에서와 같은 방법으로 실험을 수행한 후 시료 처리가 끝난 세포에서 단백질을 분리하여 지방 생성 관련 단백질의 발현 변화를 Western blot hybridization으로 분석하였다. 먼저 시료 처리가 끝난 배양 세포에서 cell lysate 를 추출하여 Bradford assay로 단백질 농도를 결정한 후 50 $\mu \mathrm{g}$ 의 단백질을 $10 \%$ sodium dodecyl sulfate-polyacrylamide gel electrophoresis (SDS-PAGE)로 전기영동하고 nitrocellulose membrane에 blotting한 후 대상 단백질의 일차 항체 와 hybridization하였다. 실험에 사용한 $\mathrm{C} / \mathrm{EBPa}$ 와 $\mathrm{C} / \mathrm{EBP} \beta$ 의 일차 항체는 Cell Signaling Technology (Beverly, MA, USA) 로 부터 구입하였고, PPAR $\gamma$ 및 actin의 일차 항체와 horse radish peroxidase가 부착된 anti-goat, anti-rabbit 등의 이차 항체는 Santa Cruz Biotechnology Inc. (Santa Cruz, CA, USA) 로부터 구입하여 사용하였다. Membrane 수세 후 이차 항체로 한 시간 동안 반응시키고 chemiluminescence detection system (FluoChem ${ }^{\circledR} \mathrm{FC} 2$, AlphaInnotech, USA)을 이용하여 각
단백질의 발현을 분석하였다.

\section{통계 분석}

실험의 결과는 평균(mean)표준편차(standard deviation, $\mathrm{SD}$ )로 나타내었고, 각 데이터의 통계 분석은 unpaired Student's $t$-test를 통해 $p$ 값이 0.05 미만 $(p<0.05)$ 인 경우 유의성이 있는 것으로 판단하였다.

\section{결과 및 고찰}

\section{머루근 추출물 및 분획물의 제조}

본 실험에 사용한 머루근 $\mathrm{MeOH}$ 추출물(VARM) 및 용매 분획물의 제조 과정은 Fig. 4 에 제시된 바와 같다. $5 \mathrm{~kg}$ 의 머루 근 시료로부터 $527.6 \mathrm{~g}$ 의 VARM을 확보하여 그 수율은 $10.6 \%$ 였고 VARM으로부터 얻은 각 분획물의 양은 $\mathrm{CH}_{2} \mathrm{Cl}_{2}, \mathrm{EtOAc}$, $n-\mathrm{BuOH}, \mathrm{H}_{2} \mathrm{O}$ 층이 각각 21.3, 81.1, 71.3, $246.1 \mathrm{~g}$ 으로 그 수율 은 4.0,15.4, 13.5, 46.6\%로 나타났다.

\section{머루근 추출물이 3T3-L1 preadipocyte의 세포 생존율에 미치는 영향}

머루근 추출물의 지방 생성 억제능의 평가를 위해 먼저 VARM이 3T3-L1 preadipocyte의 세포 생존율에 미치는 영향 을 WST assay를 이용하여 분석하였다. 그 결과 Fig. $1 \mathrm{~A}$ 에 제시 한 바와 같이 0 에서 $1,000 \mu \mathrm{g} / \mathrm{ml}$ 의 처리 농도 범위에서 세포독 성을 거의 유발하지 않았으며 특히 $1,000 \mu \mathrm{g} / \mathrm{ml}$ 의 고농도 처 리에 의해서도 세포생존율이 $92 \%$ 로 높게 나타나 머루근 추출 물이 낮은 독성의 안전성이 높은 소재임을 확인하였다. 이에 먼저 VARM의 지방 생성 억제능의 분석을 0 에서 $1,000 \mu \mathrm{g} / \mathrm{ml}$ 까지 다양한 농도 범위에서 분석하였다.

머루근 추출물이 MDI로 유도한 3T3-L1 preadipocyte의 adipogenesis에 미치는 영향

머루근 추출물의 항비만 활성 보유 유무를 알아보기 위해 MDI로 분화를 유도한 3T3-L1 preadipocyte의 adipogenesis에 $\mathrm{VARM}$ 이 미치는 영향을 살펴보았다. 그 결과 Fig. $1 \mathrm{~B}$ 에 제시 된 바와 같이 처리한 모든 농도 범위에서 지방 세포 분화가

Table 1. Primer sequences used for RT-PCR

\begin{tabular}{cll}
\hline Gene name & Sequence \\
\hline \multirow{2}{*}{ C/EBPa } & Sense & $5^{\prime}$-GTG TGC ACG TCT ATG CTA AAC CA-3' \\
& Antisense & $5^{\prime}$-GCC GTT AGT GAA GAG TCT CAG TTT G-3' \\
\hline \multirow{2}{*}{ C/EBP $\beta$} & Sense & $5^{\prime}$-GTT TCG GGA GTT GAT GCA ATC-3' \\
& Antisense & $5^{\prime}$-AAC AAC CCC GCA GGA ACA T-3' \\
\hline \multirow{2}{*}{ PPARr } & Sense & $5^{\prime}$-CGC TGA TGC ACT GCC TAT GA-3' \\
& Antisense & $5^{\prime}$-TGC GAG TGG TCT TCC ATC AC-3' \\
\hline \multirow{2}{*}{ GAPDH } & Sense & $5^{\prime}$-GGG AGT CAA CGG ATT TGG TCG TAT-3' \\
& Antisense & $5^{\prime}$-AGC CTT CTC CAT GGT GGT GAA GAC-3' \\
\hline
\end{tabular}


(A)

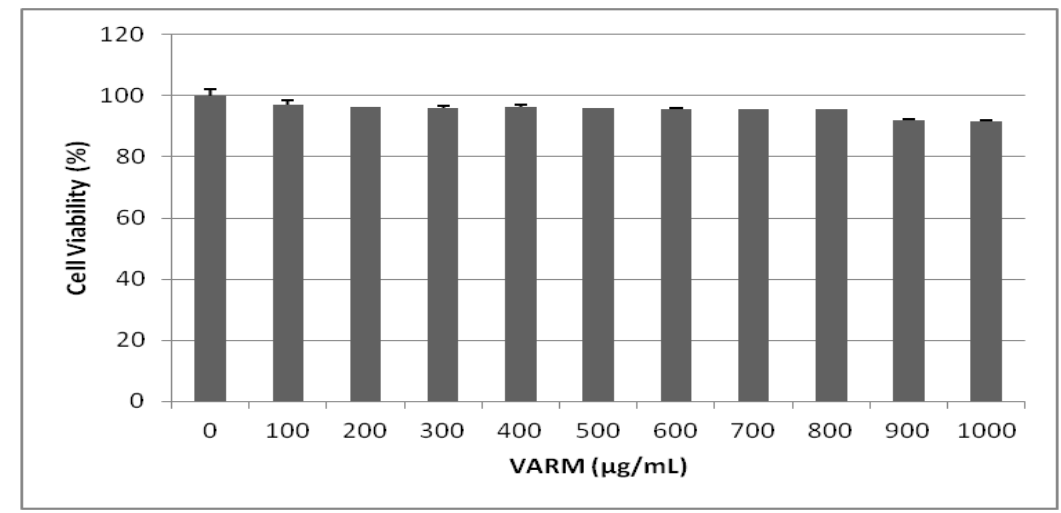

(B)

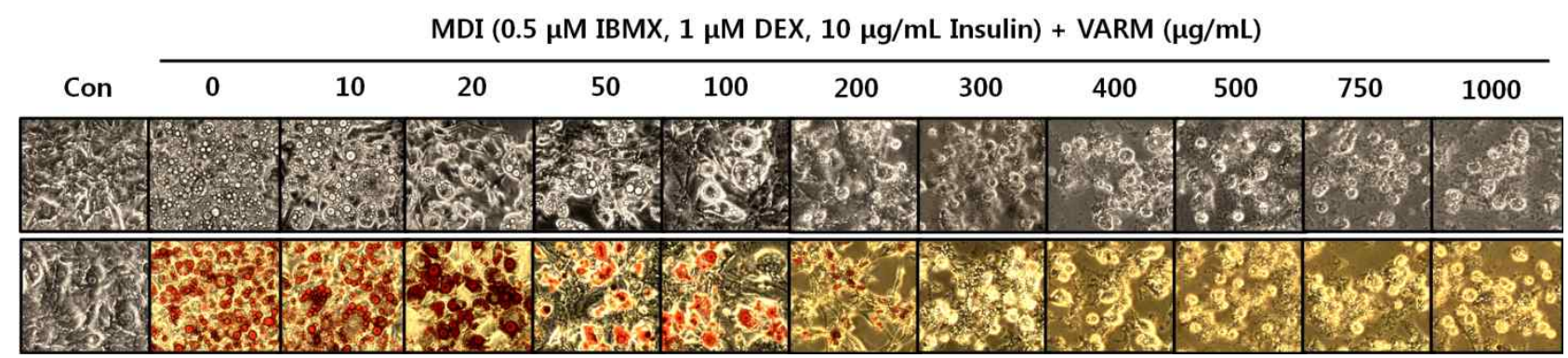

(C)

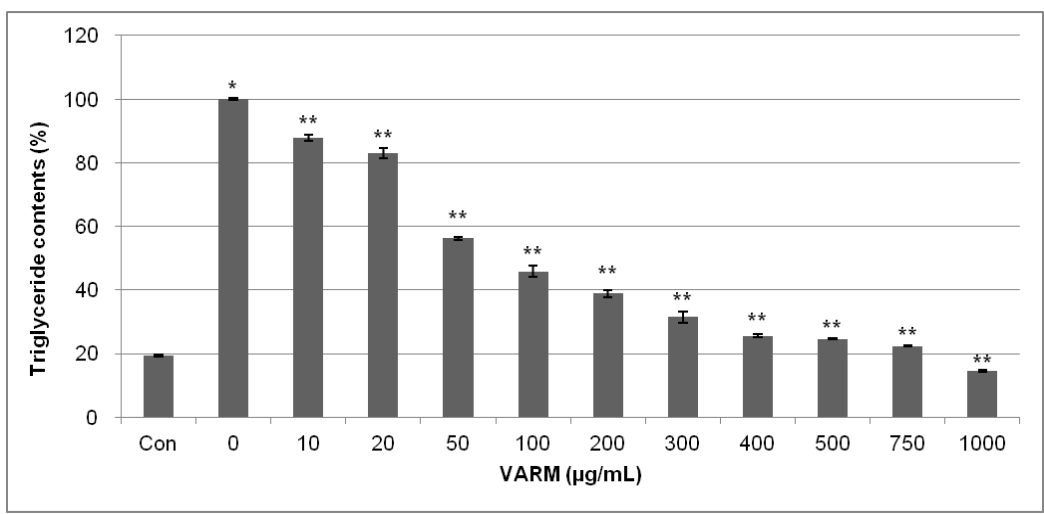

Fig. 1. Effect of VARM on 3T3-L1 cell proliferation (A), morphological change and lipid accumulation (B), and triglyceride (TG) contents (C). (A) Cells were treated with the indicated concentrations of VARM for $72 \mathrm{hr}$ and viability was determined by WST assay. Data are expressed as the mean \pm SD of triplicate experiments. (B) Differentiation of confluent 3T3-L1 preadipocytes was initiated with MDI treatment and maintained in DMEM containing 5\% FBS in presence and absence of VARM. After day 8, cells were fixed and stained with Oil Red O. The morphological change and lipid droplet accumulation were visualized using by inverted microscopy (x200). (C) TG contents were determined by Oil Red O staining after treatment of VARM. TG contents were measured at $500 \mathrm{~nm}$ by multi-plate reader. Data are expressed as the mean $\pm \mathrm{SD}$ of triplicate experiments. *, **Significantly different from the undifferentiated cell control (Con) and untreated cell control (0), respectively $(p<0.05)$.

농도 의존적으로 강하게 억제되었고 Oil Red O staining 결과 염색된 지방의 수가 급격히 감소됨을 확인할 수 있었다. 지방 생성의 억제 정도를 정량적으로 평가하기 위해 염색된 지방을 추출하여 TG 생성량의 정도를 측정한 결과 10 에서 $1,000 \mu \mathrm{g} /$ $\mathrm{ml}$ 의 시료 처리 범위에서 농도의존적으로 유의적인 감소를 나타내어 억제능의 정도는 $10,50,100,200,500,1,000 \mu \mathrm{g} / \mathrm{ml}$ 의 처리에 의해 각각 $12,44,54,61,75,86 \%$ 로 나타났다. 이러 한 결과를 통해 산출한 지방 생성 저해능의 $50 \%$ 억제농도 
(Inhibitory concentration), 즉 $\mathrm{IC}_{50}$ 값이 $80 \mathrm{\mu g} / \mathrm{ml}$ 로 나타나 머루근 추출물이 비교적 낮은 농도에서도 높은 지방 생성 억 제능을 보유함을 확인하였다(Fig. 1C). 이러한 결과를 통해 머 루근이 낮은 독성과 높은 지방 생성 억제능을 보유함을 확인 하였으며 이에 머루근에 함유된 항비만 활성 보유 성분을 분 리·동정할 필요성이 제기되었다.

머루근 추출물 및 분획물의 세포 독성 및 adipogenesis에 미치는 영향

머루근 추출물의 항비만 활성 보유 물질의 분리를 위해 용매 분획을 실시한 후 먼저 VARM과 각 용매 분획물이 3T3-L1 preadipocyte의 세포 생존율에 미치는 영향을 비교 분석하였다. 그 결과 Fig. $2 \mathrm{~A}$ 에 제시된 바와 같이 VARM과 4종의 분획물 모두에서 강한 세포 독성은 관찰되지 않아 VARM, $n-\mathrm{BuOH}$,
$\mathrm{H}_{2} \mathrm{O}$ 층은 $1,000 \mu \mathrm{gg} / \mathrm{ml}$ 의 고농도 처리에서도 각각 $92,94,90 \%$ 의 세포생존율을 나타내었으며 EtOAc 층은 그 보다 다소 낮아 $250,500,750,1,000 \mu \mathrm{g} / \mathrm{ml}$ 의 처리에 의해 각각 $94,89,86$, $82 \%$ 의 세포생존율을 보였다. $\mathrm{CH}_{2} \mathrm{Cl}_{2}$ 층의 경우 또한 $\mathrm{EtOAc}$ 층과 유사한 경향을 보여 $250,500,750 \mathrm{\mu g} / \mathrm{ml}$ 의 처리에 의해 서는 각각 $91,86,82 \%$ 의 세포 생존율을 보였으나 $1,000 \mu \mathrm{g} / \mathrm{ml}$ 의 고농도 처리에서는 $53 \%$ 의 세포생존율을 보였다. 이와 같은 추출물 및 분획물이 3T3-L1 preadipocyte의 세포생존율에 미 치는 영향과 머루근 추출물에 의한 지방 세포 분화 억제능의 결과를 바탕으로 추출물 및 각 분획물이 $\mathrm{MDI}$ 에 의한 지방 세포로의 분화 및 지방 생성에 미치는 영향을 $100 \mu \mathrm{g} / \mathrm{ml}$ 이하 의 농도 범위에서 관찰하였다. 그 결과 Fig. $2 \mathrm{~B}, \mathrm{C}$ 에 제시한 바와 같이 $20,50,100 \mu \mathrm{g} / \mathrm{ml}$ 의 추출물 및 분획물의 처리에 의해서도 물 층을 제외한 모든 분획물에서 유의적인 지방 세

(A)

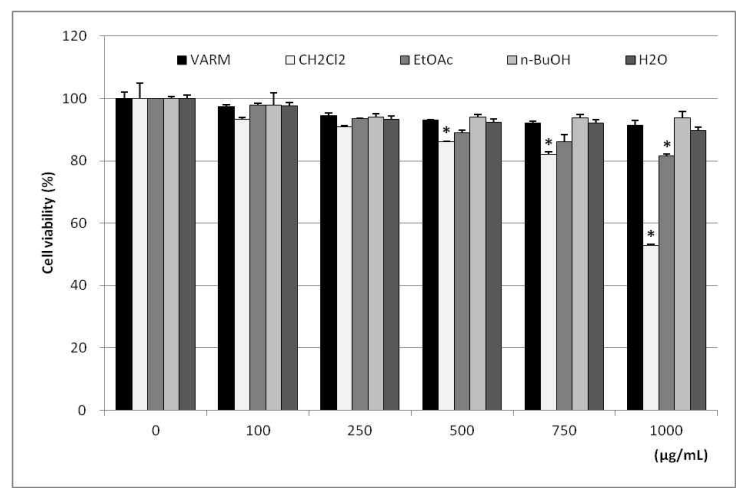

(C)

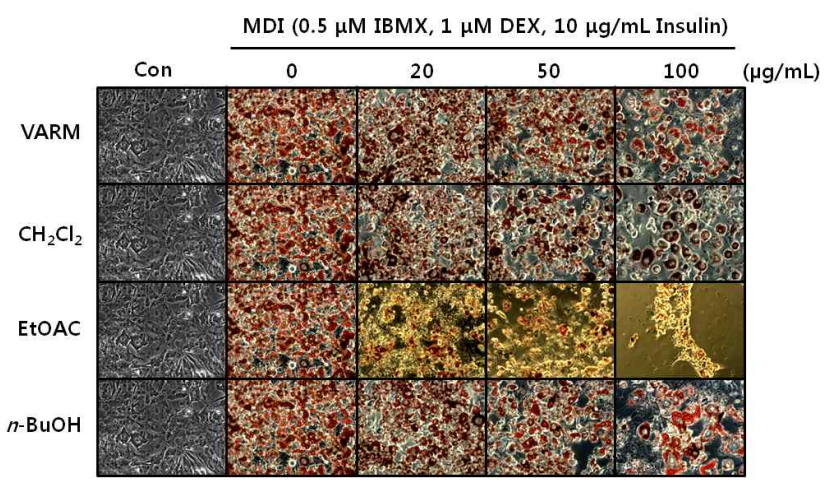

(B)

(D)
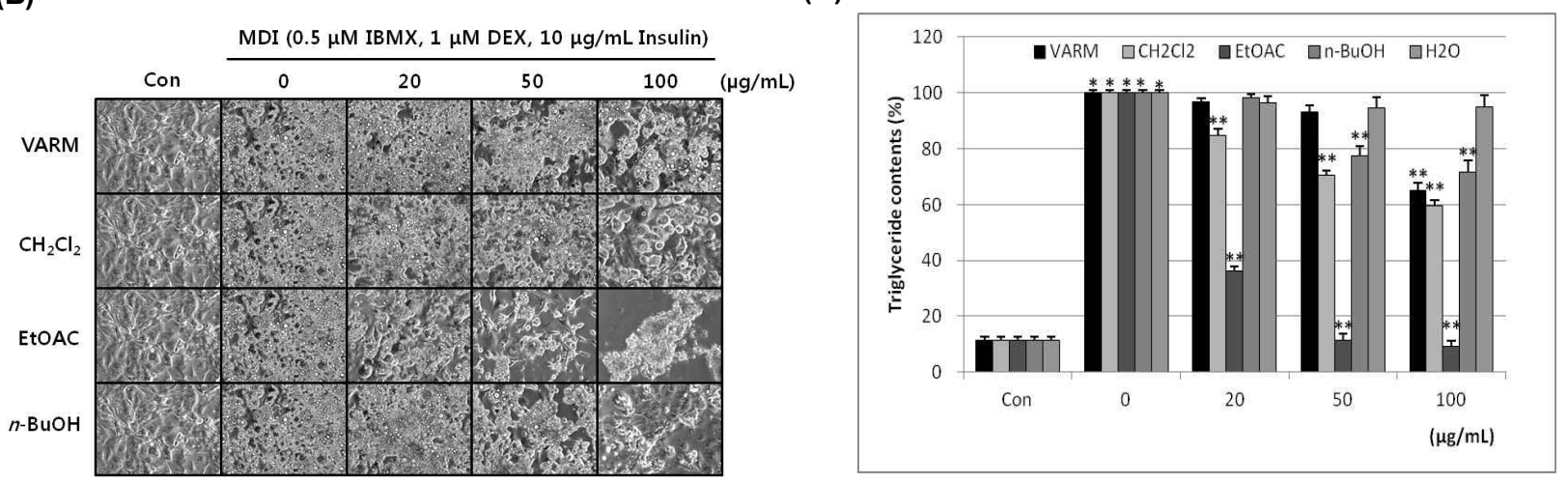

Fig. 2. Effect of VARM and its solvent fractions on 3T3-L1 cell proliferation (A), morphological change (B), lipid accumulation (C), and TG contents (D). (A) Cells were treated with the indicated concentrations of VARM and its solvent fractions such as $\mathrm{CH}_{2} \mathrm{Cl}_{2}$, EtOAc, $n-\mathrm{BuOH}$, and $\mathrm{H}_{2} \mathrm{O}$ for $72 \mathrm{hr}$ and viability was determined by WST assay. Data are expressed as the mean \pm SD of triplicate experiments. *Significantly different from vehicle control $(0)(p<0.05)$. (B, C) Differentiation of confluent 3T3-L1 preadipocytes was initiated with MDI treatment and maintained in DMEM containing 5\% FBS in presence and absence of VARM and its solvent fractions. After day 8, cells were fixed and stained with Oil Red O. The morphological change and lipid droplet accumulation were visualized using by inverted microscopy (x200). (D) TG contents were determined by Oil Red O staining after treatment of VARM and its solvent fractions. TG contents were measured at $500 \mathrm{~nm}$ by multi-plate reader. Data are expressed as the mean $\pm \mathrm{SD}$ of triplicate experiments. ${ }^{*}{ }^{*}$ Significantly different from the undifferentiated cell control (Con) and untreated cell control (0), respectively $(p<0.05)$. 
포 분화 억제능을 보였으며 Fig. $2 \mathrm{D}$ 에 제시된 바와 같이 농도 의존적인 TG 생성 억제능을 보였다. 지방 생성 억제능의 정도 는 $\mathrm{EtOAc}, \mathrm{CH}_{2} \mathrm{Cl}_{2}, n \mathrm{BuOH}$ 층의 순으로 $\mathrm{EtOAc}$ 층에서 가장 높게 나타났으나 세포 생존율 측정에서는 독성을 나타내지 않았던 EtOAc 층 분획물이 분화된 지방세포에서는 독성을 보 이는 것으로 판단되어 미분화 세포와 분화된 지방세포 모두에 서 독성의 유발 없이 높은 지방생성 억제능을 보유하면서 그 활성의 정도가 가장 강하게 나타난 $\mathrm{CH}_{2} \mathrm{Cl}_{2}$ 층 분획물을 대상

(A)

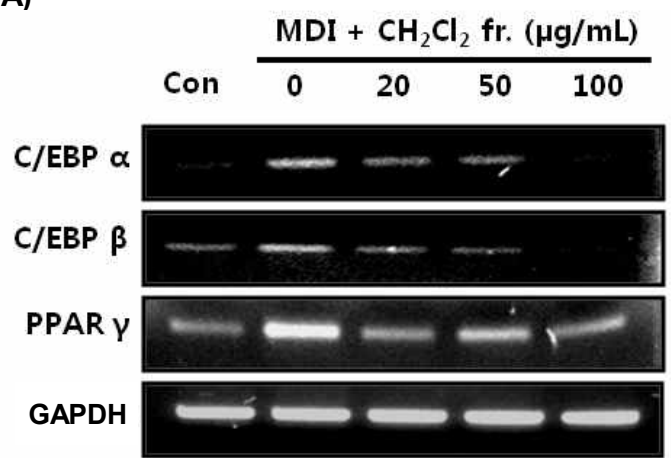

으로 이후 실험을 수행하였다.

머루근 추출물 $\mathrm{CH}_{2} \mathrm{Cl}_{2}$ 층 분획물이 adipogenesis 관련 유전자 및 단백질 발현에 미치는 영향

Preadipocyte가 adipocyte로 분화되는 adipogenesis의 과 정에는 초기(early), 중기(intermediate), 후기(late)의 각 단계 별로 중요한 분화 조절자들이 관여한다. MDI 처리 초기에는 가장 먼저 c-fos, c-jun, c-myc 등의 유전자 발현이 증가하며 이

(B)

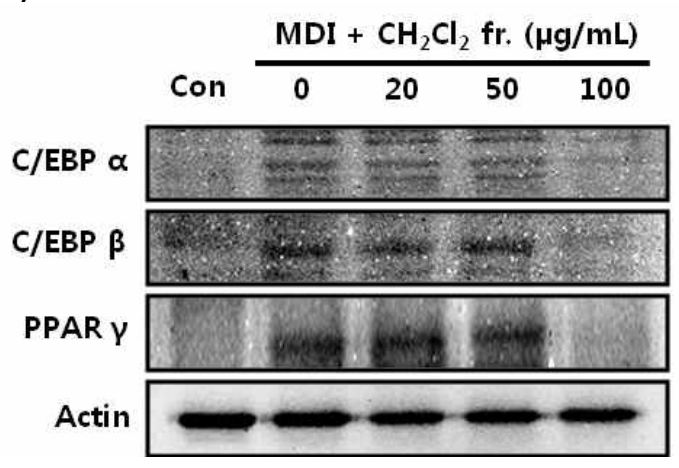

Fig. 3. Effect of $\mathrm{CH}_{2} \mathrm{Cl}_{2}$ fraction of VARM on adipogenesis related gene (A) and protein (B) expressions. (A) Modulation of adipogenic transcription factors by $\mathrm{CH}_{2} \mathrm{Cl}_{2}$ fraction of VARM was evaluated by RT-PCR. GAPDH was used as an internal control. (B) Modulation of adipogenesis related protein expressions by $\mathrm{CH}_{2} \mathrm{Cl}_{2}$ fraction of VARM was evaluated by Western blot analysis. Actin was used as an internal control.

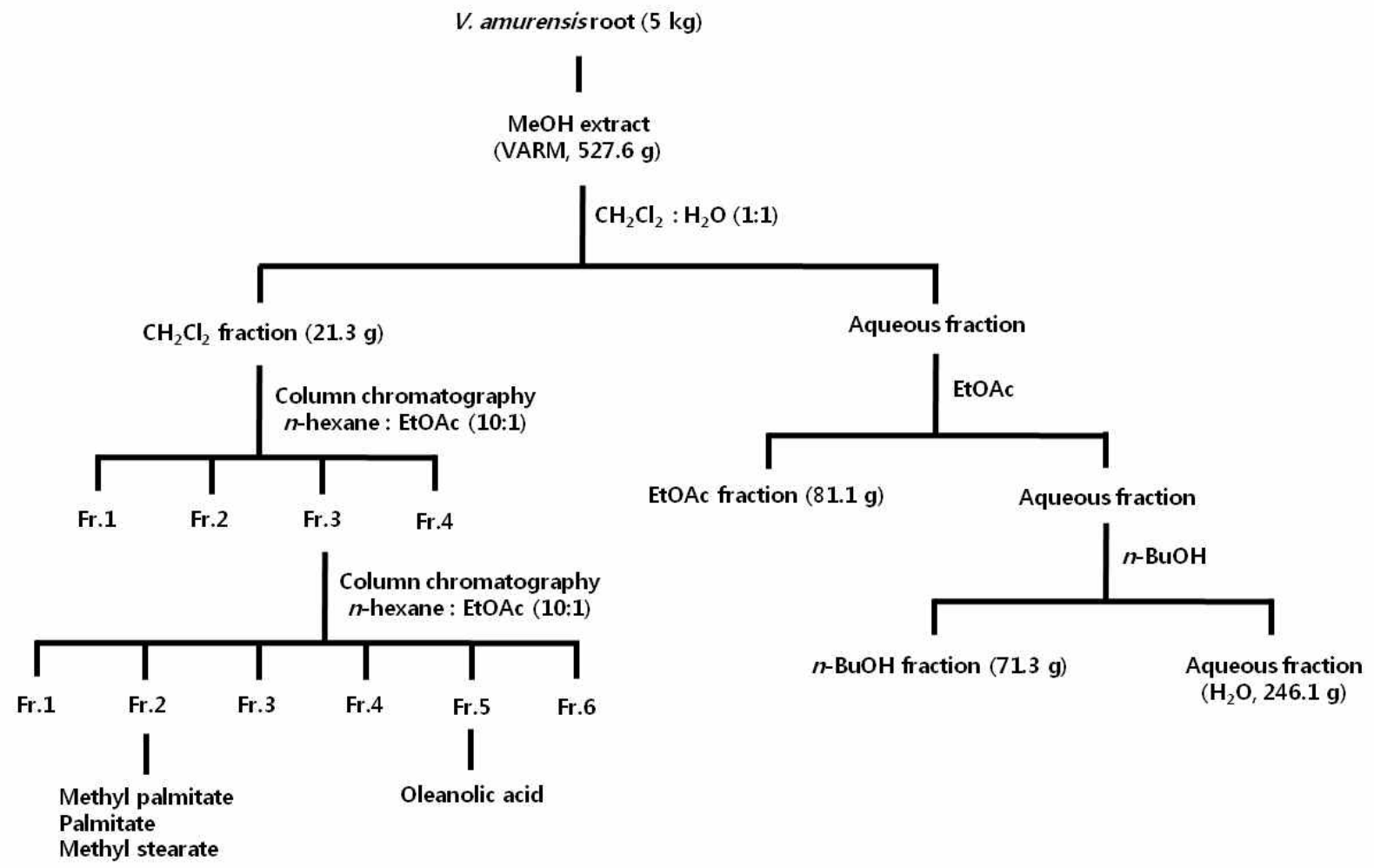

Fig. 4. Procedure of VARM extraction, fractionation of each solvent fraction and isolation of active compounds serially from $V$. amurensis root. 
(A)

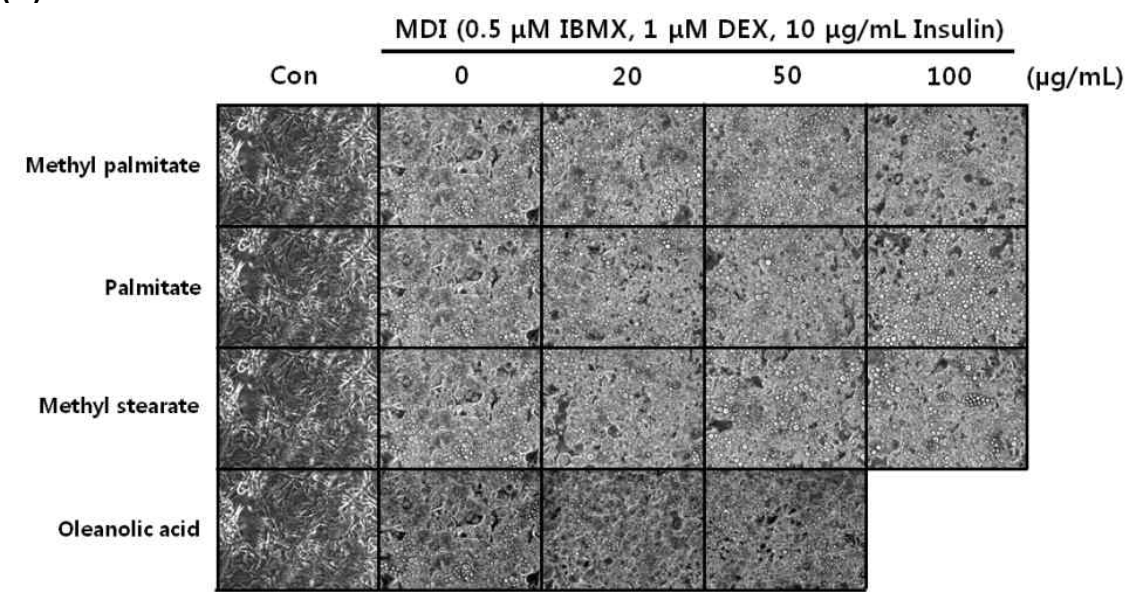

(B)

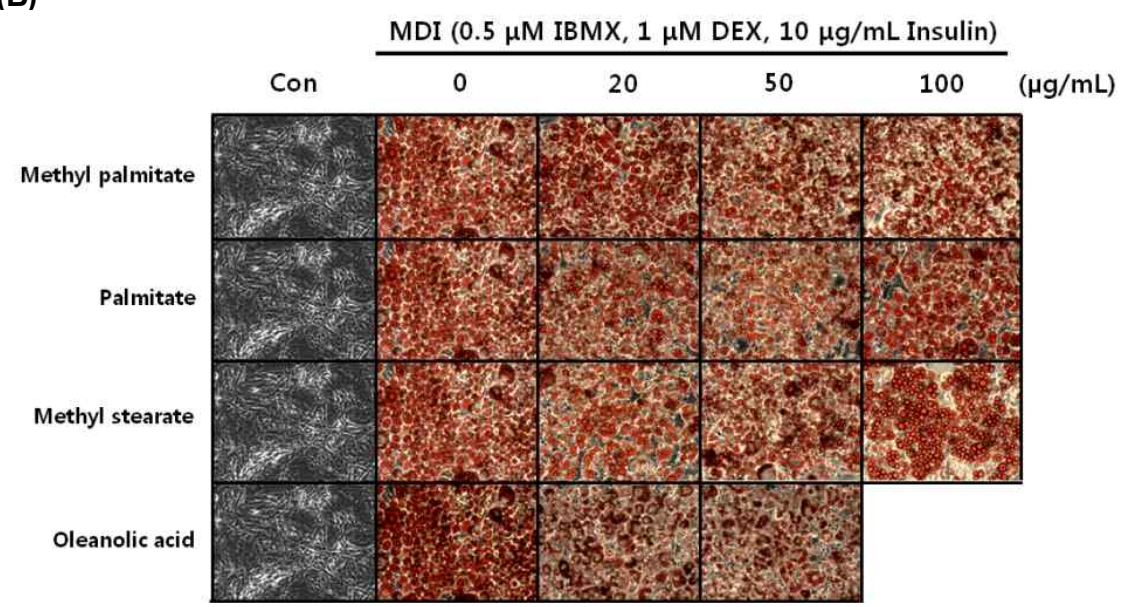

(C)

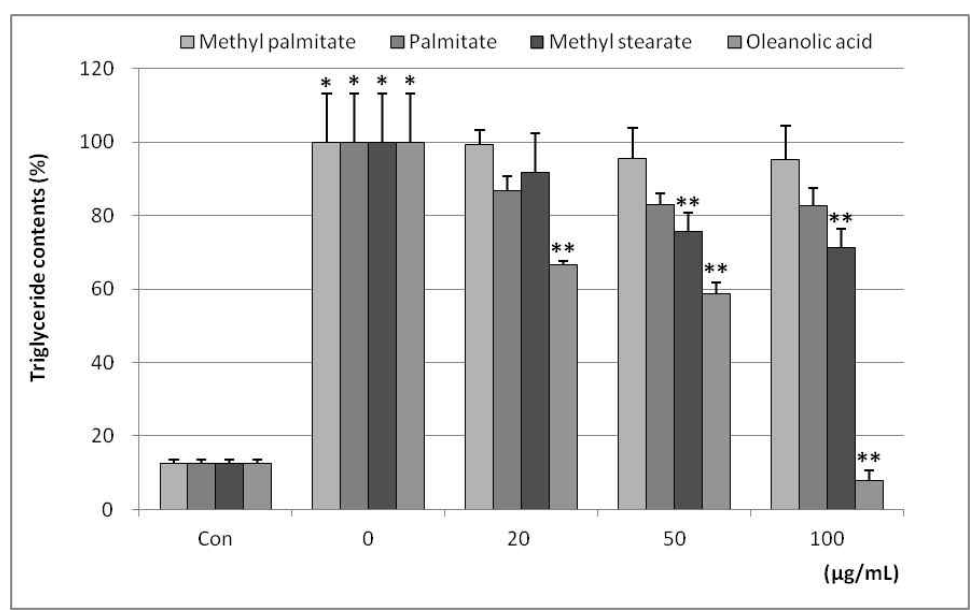

Fig. 5. Effect of four active compounds originated from $\mathrm{CH}_{2} \mathrm{Cl}_{2}$ fraction of VARM on morphological change (A), lipid accumulation (B), and TG contents (C). Differentiation of confluent 3T3-L1 preadipocytes was initiated with MDI treatment and maintained in DMEM containing 5\% FBS in presence and absence of each chemical. After day 8, cells were fixed and stained with Oil Red O. The morphological change and lipid droplet accumulation were visualized using by inverted microscopy (x200). TG contents were determined by Oil Red O staining after treatment of each chemical and measured at $500 \mathrm{~nm}$ by multi-plate reader. Data are expressed as the mean \pm SD of triplicate experiments. ${ }^{*}$ **Significantly different from the undifferentiated cell control (Con) and untreated cell control (0), respectively $(p<0.05)$. 
와 함께 C/EBP 3 와 $\delta$ 의 발현 또한 유도된다. C/EBP 3 와 $\delta$ 는 preadipocyte가 MDI 등의 differentiation cocktail에 노출되었 을 때 분화 초기에 가장 먼저 작용하는 전사 인자(transcription factor)로 $\mathrm{MDI}$ 의 경우 $\mathrm{C} / \mathrm{EBP} \beta$ 는 $\mathrm{DEX}$ 에, $\mathrm{C} / \mathrm{EBP} \delta$ 는 IBMX에 의해 활성이 유도되는 것으로 알려져 있다. 이러한 $\mathrm{C} / \mathrm{EBP} \beta$ 와 $\delta$ 의 활성은 분화 중기 및 후기에서 작용하는 $\operatorname{PPAR} \gamma$ 와 $\mathrm{C} / \mathrm{EBPa}$ 의 발현 매개인자로서, 활성화된 $\mathrm{PPAR} \gamma$ 와 $\mathrm{C} / \mathrm{EBPa}$ 는 단독 혹은 상호작용을 통해 지방세포 특이적 유전자의 발 현(adipocyte specific gene expression)을 유도하여 지방 세포 분화 및 지방 형성을 완성한다[24]. 따라서 이와 같은 지방 세 포 분화에 관여하는 주요 인자들의 발현 조절 유무는 소재가 보유한 지방 생성 억제능 및 그 작용 기전을 판단하는 주요 방법 중 하나이다.

본 연구에서는 머루근이 보유한 지방 생성 억제능의 작용 기전을 알아보기 위해 $\mathrm{CH}_{2} \mathrm{Cl}_{2}$ 층 분획물을 사용하여 adipogenesis에 관여하는 주요 핵심 조절자인 $\mathrm{C} / \mathrm{EBPa}, \mathrm{C} / \mathrm{EBP} \beta$, 그리고 PPAR $\gamma$ 의 유전자 및 단백질 발현을 분석하였다. 그 결과 Fig. 3에 제시된 바와 같이 MDI 처리에 의해 지방세포 분화가 일어난 대조군에서는 세 인자의 유전자 및 단백질 발 현이 유의적으로 증가되었으며 머루근 $\mathrm{CH}_{2} \mathrm{Cl}_{2}$ 층 분획물의 처리에 의해 감소함을 보였다. 특히 세 인자의 유전자 발현은 $20 \mu \mathrm{g} / \mathrm{ml}$ 의 처리에서부터 급격히 감소되었으며, 특히 C/EBP $\mathrm{a}, \beta$ 의 경우 $100 \mathrm{\mu g} / \mathrm{ml}$ 에서는 발현이 완전히 억제됨을 보였 다(Fig. 3A). 단백질 발현은 유전자 발현에서와 같이 저농도에 서 뚜렷한 발현 저해는 관찰되지 않았으나 $100 \mathrm{\mu g} / \mathrm{ml}$ 에서는 발현이 강하게 억제되었다(Fig. $3 \mathrm{~B}$ ). 이러한 결과는 머루근이 보유한 항비만 활성이 adipogenesis에 관여하는 핵심 인자의 유전자 및 단백질 발현 저해의 기작을 통해 이루어짐을 시사 한다.

\section{머루근 $\mathrm{CH}_{2} \mathrm{Cl}_{2}$ 층 유래 화합물 4종의 항비만 활성 분석}

머루근이 보유한 항비만 활성의 핵심 작용 물질을 찾아내기 위해 Fig. 4 에서와 같이 $\mathrm{CH}_{2} \mathrm{Cl}_{2}$ 층으로부터 물질 분리를 수행 하였다. $\mathrm{CH}_{2} \mathrm{Cl}_{2}$ 층 분획물을 $n$-hexane : EtOAc [10:1, 5:1, 3:1, 2:1, 1:1 (v/v)] 및 $\mathrm{MeOH}$ 순으로 용출시켜 silica gel column chromatography를 수행하여 분획물(fraction, Fr.) 1 4를 얻었 다. 그 중 Fr. 3을 위와 같은 용매 순으로 silica gel column chromatography를 수행하여 Fr. 1 6을 얻었다. 그 중 Fr. 2와 5의 GC-mass 분석을 통해 Fr. 2로부터 methyl palmitate, palmitate, methyl stearate, Fr. 5 로부터 oleanolic acid 등의 화합 물의 존재를 확인한 후 각 화합물을 Sigma-Aldrich Co. (St. Louis, MO, USA)로 부터 구입하여 표준품과 분리 화합물의 동일성을 thin layer chromatography (TLC)를 통해 확인한 후, 각 물질이 보유한 항비만 활성 유무를 분석하였다. 그 결과 Fig. 5에 제시된 바와 같이 methyl palmitate를 제외한 3종의 화합물이 농도의존적인 지방세포 분화 및 지방 생성 억제능을
보였다. 각 화합물의 활성의 정도는 $20,50,100 \mathrm{\mu g} / \mathrm{ml}$ 의 시료 처리에 의해 palmitate가 $13,17,17 \%$, methyl stearate가 8 , $24,29 \%$, 그리고 oleanolic acid가 $33,41,92 \%$ 의 지방 생성 억제 능을 보여 활성의 강도는 oleanolic acid, methyl stearate, palmitate의 순으로 나타났다. 가장 강한 활성을 보인 oleanolic acid는 식품과 약용 식물에 주로 존재하는 triterpenoid의 하나 로 올리브(Olea europaea) 잎에서 처음으로 분리되었으며 인삼 등의 식물에서 당류와 결합한 사포닌으로 함유된 경우가 많 다. 식물계에 존재하는 인체 생리 활성 물질의 하나로 낮은 독성과 간 보호능, 항염증 효과, 항암 활성, 항바이러스 활성, 신경변성질환 억제, 고지혈증 및 동맥경화 억제능 등이 보고 된 봐 있다[22, 26]. 한편 oleanolic acid의 지방 분화 인자 발현 조절을 통한 지방세포 분화 억제능 및 고지방 식이 실험 동물 에서의 항비만 활성 등이 선행문헌에서 보고된 바 있으나[3, 30] 본 실험의 소재로 사용한 머루근에서 발견된 것은 본 연구 가 처음이다.

이상의 결과를 통해 머루근 추출물 및 분획물이 낮은 독성 과 높은 항비만 활성을 보유함을 확인하였으며, 활성 보유 화 합물 중 하나로 $\mathrm{CH}_{2} \mathrm{Cl}_{2}$ 층 분획물에서 oleanolic acid를 분리하 였다. 이러한 결과는 한방에서 약재로 사용되고 있으나 그 생 리활성이 명확히 규명되지 않은 머루근의 다양한 생리활성을 과학적으로 규명함으로써 향후 항비만 활성 보유 기능성 식품 및 소재로서의 활용을 위한 근거자료로 활용될 수 있을 것으 로 판단된다.

\section{감사의 글}

이 연구는 지식경제부·부산광역시 지원 지역혁신센터사 업(RIC08-06-07) 동의대학교 블루바이오 소재 개발 및 실용화 지원 센터의 지원으로 이루어 졌습니다.

\section{References}

1. Bak, M. J., Jun, M. and Jeong, W. S. 2012. Procyanidins from wild grape (Vitis amurensis) seeds regulate ARE-mediated enzyme expression via Nrf2 coupled with p38 and PI3K/Akt pathway in HepG2 cells. Int J Mol Sci 13, 801-818.

2. Chen, H. C. and Farese, R. V. 2005. Inhibition of triglyceride synthesis as a treatment strategy for obesity: lessons from DGAT1-deficient mice. Arterioscler Thromb Vasc Biol 25, 482-486.

3. de Melo, C. L., Queiroz, M. G., Fonseca, S. G., Bizerra, A. M., Lemos, T. L., Melo, T. S., Santos, F. A. and Rao, V. S. 2010. Oleanolic acid, a natural triterpenoid improves blood glucose tolerance in normal mice and ameliorates visceral obesity in mice fed a high-fat diet. Chem Biol Interact 185, 59-65.

4. Dubrovina, A. S., Manyakhin, A. Y., Zhuravlev, Y. N. and Kiselev, K. V. 2010. Resveratrol content and expression of 
phenylalanine ammonia-lyase and stilbene synthase genes in rolC transgenic cell cultures of Vitis amurensis. Appl Microbiol Biotechnol 88, 727-736.

5. Fox, K. E., Fankell, D. M., Erickson, P. F., Majka, S. M., Crossno, J. T. and Klemm, D. J. 2006. Depletion of cAMP-response element-binding protein/ATF1 inhibits adipogenic conversion of 3T3-L1 cells ectopically expressing CCAAT/ enhancer-binding protein (C/EBP) alpha, C/EBP beta, or PPAR gamma 2. J Biol Chem 281, 40341-40353.

6. Green, H. and Meuth, M. 1974. An established pre-adipose cell line and its differentiation in culture. Cell 3, 127-133.

7. Haslam, D. W. and James, W. P. 2005. Obesity. Lancet 366, 1197-1209.

8. Hien, T. T., Oh, W. K., Quyen, B. T., Dao, T. T., Yoon, J. H., Yun, S. Y. and Kang, K. W. 2012. Potent vasodilation effect of amurensin $G$ is mediated through the phosphorylation of endothelial nitric oxide synthase. Biochem Pharmacol 84, 1437-1450.

9. Huang, K. S. and Lin, M. 1999. Oligostilbenes from the roots of Vitis amurensis. J Asian Nat Prod Res 2, 21-28.

10. Huang, K. S., Lin, M. and Cheng, G. F. 2001. Anti-inflammatory tetramers of resveratrol from the roots of Vitis amurensis and the conformations of the seven-membered ring in some oligostilbenes. Phytochemistry 58, 357-362.

11. Jang, M. H., Piao, W. L., Kim, J. M., Kwon, S. W. and Park, J. H. 2008. Inhibition of cholinesterase and amyloid-beta aggregation by resveratrol oligomers from Vitis amurensis. Phytother Res 22, 544-549.

12. Jeong, H. Y., Kim, J. Y., Lee, H. K., Ha do, T., Song, K. S., Bae, K. and Seong, Y. H. 2010. Leaf and stem of Vitis amurensis and its active components protect against amyloid $\beta$ protein (25-35)-induced neurotoxicity. Arch Pharm Res 33, 1655-1664.

13. Jessen, B. A. and Stevens, G. J. 2002. Expression profiling during adipocyte differentiation of 3T3-L1 fibroblasts. Gene 299, 95-100.

14. Kim, H. J., Kang, C. H. and Kim, S. K. 2012. Anti-adipogenic effect of Undaria pinnatifida extracts by ethanol in 3T3-L1 adipocytes. J Life Sci 22, 1052-1056.

15. Kim, J. A., Kim, M. R., Kim, O., Phuong, N. T., Yoon, J., Oh, W. K., Bae, K. and Kang, K. W. 2012. Amurensin G inhibits angiogenesis and tumor growth of tamoxifen-resistant breast cancer via Pin1 inhibition. Food Chem Toxicol 50, 3625-3634.

16. Kim, J. Y., Jeong, H. Y., Lee, H. K., Kim, S., Hwang, B. Y., Bae, K. and Seong, Y. H. 2012. Neuroprotection of the leaf and stem of Vitis amurensis and their active compounds against ischemic brain damage in rats and excitotoxicity in cultured neurons. Phytomedicine 19, 150-159.

17. Kim, S. H., Kwon, T. K. and Shin, T. Y. 2008. Antiallergic effects of Vitis amurensis on mast cell-mediated allergy model. Exp Biol Med (Maywood) 233, 192-199.

18. Koutnikova, H. and Auwerx, J. 2001. Regulation of adipocyte differentiation. Ann Med 33, 556-561.

19. Lee, E. O., Kwon, B. M., Song, G. Y., Chae, C. H., Kim, H. M., Shim, I. S., Ahn, K. S. and Kim, S. H. 2004. Heyneanol
A induces apoptosis via cytochrome c release and caspase activation in human leukemic U937 cells. J Life Sci 74, 2313-2326.

20. Lee, E. O., Lee, H. J., Hwang, H. S., Ahn, K. S., Chae, C., Kang, K. S., Lu, J. and Kim, S. H. 2006. Potent inhibition of Lewis lung cancer growth by heyneanol A from the roots of Vitis amurensis through apoptotic and anti-angiogenic activities. Carcinogenesis 27, 2059-2069.

21. Leung, W. Y., Thomas, G. N., Chan, J. C. and Tomlinson, B. 2003. Weight management and current options in pharmacotherapy: orlistat and sibutramine. Clin Ther 25, 58-80.

22. Liu, J. 1995. Pharmacology of oleanolic acid and ursolic acid. J Ethnopharmacol 49, 57-68.

23. Morrison, R. F. and Farmer, S. R. 2000. Hormonal signaling and transcriptional control of adipocyte differentiation. $J$ Nutr 130, 3116S-3121S.

24. Ntambi, J. M. and Kim, Y. C. 2000. Adipocyte differentiation and gene expression. J Nutr 130, 3122S-3126S.

25. Park, J. A., Park, C., Han, M. H., Kim, B. W., Chung, Y. H. and Choi, Y. H. 2011. Inhibition of adipocyte differentiation and adipogenesis by aged black garlic extracts in 3T3-L1 preadipocytes. J Life Sci 21, 720-728.

26. Pollier, J. and Goossens, A. 2012. Oleanolic acid. Phytochemistry 77, 10-15.

27. Rosen, E. D. and Spiegelman, B. M. 2000. Molecular regulation of adipogenesis. Annu Rev Cell Dev Biol 16, 145-171.

28. Schroeder-Gloeckler, J. M., Rahman, S. M., Janssen, R. C., Qiao, L., Shao, J., Roper, M., Fischer, S. J., Lowe, E., Orlicky, D. J., McManaman, J. L., Palmer, C., Gitomer, W. L., Huang, W., O'Doherty, R. M., Becker, T. C., Klemm, D. J., Jensen, D. R., Pulawa, L. K., Eckel, R. H. and Friedman, J. E. 2007. CCAAT/enhancer-binding protein beta deletion reduces adiposity, hepatic steatosis, and diabetes in Lepr $(\mathrm{db} / \mathrm{db})$ mice. J Biol Chem 282, 15717-15729.

29. Shin, T. Y. and Kim, S. H. 2011. Meoruh wine suppresses mast cell-mediated allergic inflammation. Immnopharmacol Immunotoxicol 33, 271-278.

30. Sung, H. Y., Kang, S. W., Kim, J. L., Li, J., Lee, E. S., Gong, J. H., Han, S. J. and Kang, Y. H. 2010. Oleanolic acid reduces markers of differentiation in 3T3-L1 adipocytes. Nutr Res 30, 831-839.

31. Suzuki, R., Tanaka, M., Takanashi, M., Hussain, A., Yuan, B., Toyoda, H. and Kuroda, M. 2011. Anthocyanidins-enriched bilberry extracts inhibit 3T3-L1 adipocyte differentiation via the insulin pathway. Nutr Metab (Lond) 8, 14 .

32. Wang, J. N., Hano, Y., Nomura, T. and Chen, Y. J. 2000. Procyanidins from the seeds of Vitis amurensis. Phytochemistry 53, 1097-1102.

33. Wang, J. N., Chen, Y. J., Hano, Y., Nomura, T. and Tan, R. X. 2000. Antioxidant activity of polyphenols from seeds of Vitis amurensis in vitro. Acta Pharmacol Sin 21, 633-636.

34. Wang, N. D., Finegold, M. J., Bradley, A., Ou, C. N., Abdelsayed, S. V., Wilde, M. D., Taylor, L. R., Wilson, D. R. and Darlington, G. J. 1995. Impaired energy homeostasis in C/EBP alpha knockout mice. Science 269, 1108-1112.

35. Weidner, S., Powalka, A., Karamac, M. and Amarowicz, R. 
2012. Extracts of phenolic compounds from seeds of three wild grapevines-comparison of their antioxidant activities and the content of phenolic compounds. Int J Mol Sci 13, 3444-3457.

36. Wu, Z., Rosen, E. D., Brun, R., Hauser, S., Adelmant, G., Troy, A. E., McKeon, C., Darlington, G. J. and Spiegelman, B. M. 1999. Cross-regulation of C/EBP $a$ and PPAR $\gamma$ controls the transcriptional pathway of adipogenesis and insulin sensitivity. Mol Cell 3, 151-158.

37. Yim, N., Ha do, T., Trung, T. N., Kim, J. P., Lee, S., Na, M., Jung, H., Kim, H. S., Kim, Y. H. and Bae, K. 2010. The antimicrobial activity of compounds from the leaf and stem of Vitis amurensis against two oral pathogens. Bioorg Med Chem Lett 20, 1165-1168.

\section{초록 : 머루근 추출물 및 분획물의 항비만 활성}

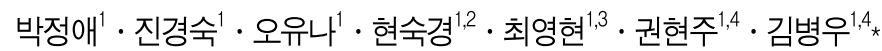

$\left({ }^{1}\right.$ 동의대학교 블루바이오소재개발 및 실용화 지원센터, ${ }^{2}$ 동의대학교 자연과학대학 식품영양학과, ${ }^{3}$ 동의 대학 교 한의과대학 생화학교실, ${ }^{4}$ 동의대학교 자연과학대학 생명응용학과)

왕머루(Vitis amurensis Rupreche)는 아시아 지역에서 자생하는 포도의 한 종류로서 항산화, 항염증, 뇌신경보 호, 신생혈관 억제능 등의 생리활성이 알려져 있다. 왕머루의 뿌리는 한국에서 전통적인 약재로 사용되어왔으나 그 생리활성에 대해서는 보고된 바가 적다. 이에 본 연구에서는 머루근 $\mathrm{MeOH}$ 추출물(VARM)과 그 용매 분획물 이 지방세포분화 및 지방 생성에 미치는 영향을 3T3-L1 preadipocyte를 이용하여 분석하였다. 그 결과 VARM은 3T3-L1 preadipocyte의 지방 세포로의 분화, 지방 축적, 중성 지방 생성량을 독성 없이 농도의존적으로 유의적으 로 억제시켰다. 활성 물질의 규명을 위해 VARM으로부터 dichloromethane $\left(\mathrm{CH}_{2} \mathrm{Cl}_{2}\right)$, ethyl acetate (EtOAc), $n$-butanol $(n-\mathrm{BuOH})$, 그리고 물 $\left(\mathrm{H}_{2} \mathrm{O}\right)$ 층의 순서로 용매 분획을 실시한 후 지방 생성에 미치는 영향을 분석한 결과 $\mathrm{H}_{2} \mathrm{O}$ 층을 제외한 모든 분획물에서 지방 생성 억제능이 관찰되었으며 특히 $\mathrm{CH}_{2} \mathrm{Cl}_{2}$ 층 분획물이 가장 강력한 항비만 활성을 보였고 이는 주요 지방 생성 전사 인자인 C/EBPa, C/EBPB, 그리고 $\operatorname{PPAR} \gamma$ 의 유전자 및 단백질 발현 조절에 의한 것으로 판단된다. 또한 머루근의 항비만 활성을 보유한 활성 물질을 분리한 결과 oleanolic acid 가 주요 물질 중의 하나로 나타났다. 이러한 결과는 머루근의 항비만 활성을 처음으로 밝혀낸 것이며 주요 활성 물질의 하나로 oleanolic acid를 확인하였다. 